\title{
An attempt to dendroclimatic reconstruction of winter temperature based on multispecies tree-ring widths and extreme years chronologies (example of Upper Silesia, Southern Poland)
}

\author{
Magdalena Opala $\cdot$ Maciej J. Mendecki
}

Received: 2 May 2012 / Accepted: 20 February 2013 / Published online: 22 March 2013

(C) The Author(s) 2013. This article is published with open access at Springerlink.com

\begin{abstract}
This study aims at investigating pre-instrumental tree-ring based winter thermal conditions from Upper Silesia, southern Poland. The Scots pine, pedunculate oak and sessile oak ring widths and the extreme index were used to reconstruct winter mean temperature back to A.D. 1770. The climate response analysis showed that the pine is the most sensitive to February (0.36) and March (0.41) temperature, the oaks were found to be sensitive to the previous December $(0.27)$ and January $(0.23)$ temperature. It was found out that the combination of temperature sensitive species and an additional extreme index in regression can improve the reconstruction, with an emphasis on more reliable reconstruction of extreme values. The elimination of variance reduction and precise reconstruction of actual values of temperature is possible by scaling. The obtained calibration/verification results suggest that, through the application of the long-term composite chronologies a detailed study of the climate variability in Upper Silesia in past centuries can be provided.
\end{abstract}

\section{Introduction}

The concept that a clear climate signal can be found in the tree species growing under limiting conditions have been used in many reference dendroclimatological studies in recent decades, concerning the reconstruction of thermal (e.g., Jacoby

\section{Opała $(\bowtie)$}

Department of Climatology, Faculty of Earth Sciences,

University of Silesia, 41-200 Sosnowiec, ul. Będzińska 60,

Poland

e-mail: mopala@us.edu.pl

M. J. Mendecki

Department of Applied Geology, Faculty of Earth Sciences, University of Silesia, 41-200 Sosnowiec, ul. Będzińska 60, Poland and D'Arrigo 1989; Vaganov et al. 1996; Rolland et al. 2000; Cook et al. 2003; Esper et al. 2003; Barber et al. 2004; Büntgen et al. 2005; Gou et al. 2008) and moisture conditions (e.g., Douglas 1914; Schulman 1956; Stockton and Meko 1975; Lara et al. 2001; Cook et al. 2004; Esper et al. 2007). However, research on past climate changes based on the use of proxies are of great importance in other regions, too. Therefore, substantial efforts have been undertaken recently to improve our understanding of climate-tree growth relationships and, as a result, obtaining better dendroclimatic estimates of past weather conditions at sites under non-limiting conditions, characterized by a mixed dendroclimatic signal, also from anthropogenically transformed ecosystems (e.g., Garciá-Suárez et al. 2009; Gea-Izquierdo et al. 2011; Wettstein et al. 2011; Crawford 2012). Contemporary research trends in dendroclimatology focused on the issues such as application of the multiple species with a different ecological spectrum in order to cover the greatest range of climatic variability (e.g., Garciá-Suárez et al. 2009; Trindade et al. 2011), thinking of the tree-ring as an archive containing several potential proxy records of climate (total and partial ring width, density variables, microanatomical measurements, ratios of stable isotopes and the extreme values of the above) (e.g., Fritts et al. 1991; Tardif and Conciatori 2006; Battipaglia et al. 2010; Chen et al. 2010; Hughes et al. 2011), development of the methodology for climate reconstruction models (e.g., Esper et al. 2005; Guiot et al. 2009; Helama et al. 2009; von Storch et al. 2009).

In temperate latitudes, air temperature is the most important climatic driver, which affects the biosphere and thus, also in the studies of the Polish past climate, the dendrochronological data deserve special attention (Przybylak et al. 2010; Przybylak 2012). Long-term tree-ring chronologies constructed for some regions of Poland allow for study of temperature variability in the scale of several centuries (Niedźwiedź 2004, 2010; Büntgen 
et al. 2007; Krapiec et al. 2009) back the last millennium (Zielski 1997; Szychowska-Krapiec 2010; Koprowski et al. 2012).

The temperature and rainfall are unquestionably responsible for the beginning of the cambium activity and the width of the xylem layers produced. Many authors found that the radial growth of pines and oaks, the most important forest tree species, growing outside the mountain areas in Poland, is mainly limited by the pre-growth season temperature (e.g., Wazny and Eckstein 1991; Zielski 1997; Cedro 2004, 2007; SzychowskaKrapiec 2010; Bronisz et al. 2012; Koprowski et al. 2012; Muter 2012). For both these taxons cold and frosty winters, low temperatures in early spring and dry summers are disadvantageous (in particular, all of these factors acting together) (Feliksik and Wilczyński 1998; Wilczyński 1999; Cedro 2007; Szychowska-Krapiec 2010; Bronisz et al. 2012). Although the period of cambial activity of pine begins in early May and lasts until the end of September, the annual growth of wood is also affected by climatic conditions in winter preceding the growth season (Ermich 1959). Similarly, in the case of oaks cambium cells begin their activity in spring yet before the buds burst and the formation of new vessels proceeds thanks to supply resources gathered before (Ermich 1959).

The prevailing role of February-March temperature in determining tree growth of pine has been applied recently in the climate reconstructions of Małopolska area (SzychowskaKrapiec 2010) and northern Poland (Koprowski et al. 2012). The precise study of the variability of winter temperature in recent centuries is critical, due to the fact that the increase in the prevalence of warm winters is regarded as a clear evidence of climate warming in Poland (Boryczka et al. 2005; Trepińska 1997).

The aim of this study was to find out the effective method for reconstruction of winter thermal conditions in Upper Silesia, southern Poland. For this purpose, different multispecies models using multivariate analysis of both treering widths chronologies and extreme years chronologies have been developed. This work tests the hypothesis that reconstruction of the air temperature record embedded in tree-rings from temperate zone could be significantly improved by using many variables (temperature sensitive species) at the same time, as well as by including an additional parameter (extreme years index - explanation of the term is given in the description of the methodology) to better reflect the real value of extreme conditions.

\section{Materials and methods}

\subsection{Study area}

The study area is located in the Upper Silesia region, within the Silesian Lowland. The area is characterized by a significant transformation of the natural environment due to human activity that began about 4,000 years ago. From the Middle Ages deforestation and water lever changes were observed. The civilisation changes in the 19th and 20th centuries led to changes in species composition; artificial pine monocultures have become characteristic to the Silesian lands. Decreased areas of mixed and deciduous forests have contributed to extensive soil erosion, the danger of windblow and insects invasion (Nyrek 1975; Janczak 1985). Between early 1950s and 1990s, especially at the turn of 1970 s and 1980s, an additional threat to forest stands was attributed to the industrial emissions of dust and gaseous pollutants (Norman 1999; Nowak 2005). Semi-natural forests occupy slightly distorted peripheral position in relation to the main industrial centers and these are usually covered by reserve protection. The field studies were carried out in nature reserves, considered to be the remnants of the Silesian Primeval Forest (Niemodlin and Komorzno Primeval Forests) forming mixed forests Pino-Quercetum. The dominant tree species in the investigated sites are: Quercus petraea, Quercus robur, Pinus sylvestris, Fagus sylvatica and Picea abies, Betula pendula, Abies alba, Larix deciduas (Michalak 1971). Soils with fluvioglacial material are generally classified as typical podzols (Kusza and Strzyszcz 2005). The investigated area is characterized by one of the warmest climates in Poland, with prevailing maritime influences. Upper Silesia experiences a relatively short winter with unstable snow cover and a long, warm summer. The study area receives an average of $600-700 \mathrm{~mm}$ of precipitation annually, while the average annual temperature ranges from $8{ }^{\circ} \mathrm{C}$ to $8.5{ }^{\circ} \mathrm{C}$ (Atlas 2008).

\subsection{Tree-ring sampling and chronologies development}

To reduce the potential non-climatic noise affecting the requested climate signal, study sites with minimal effects from human-related disturbances were selected for sampling (the nature reserves of Komorzno, Jeleni Dwór, Blok, Krzywiczyny and Jaśkowice) (Fig. 1). These sites are located between 190 and 220 ma.s.l. For sampling, core preparation, ring-width measurements, cross-dating and chronology building standard dendrochronological procedures were applied (Speer 2010). On each site, 15 specimens for one species were collected with Pressler incremental borers $(5 \mathrm{~mm})$. Cores were taken from healthy living trees, with no visible signs of stress or damage, from the upper canopy layer. Due to legal regulations, only one core was taken from each tree.

After cores preparation the total ring widths were measured to the nearest of $0.01 \mathrm{~mm}$ using LINTAB 6 device with a microscope and TSAPWin software (Rinn 2010). The 
Fig. 1 Location of the sampling sites

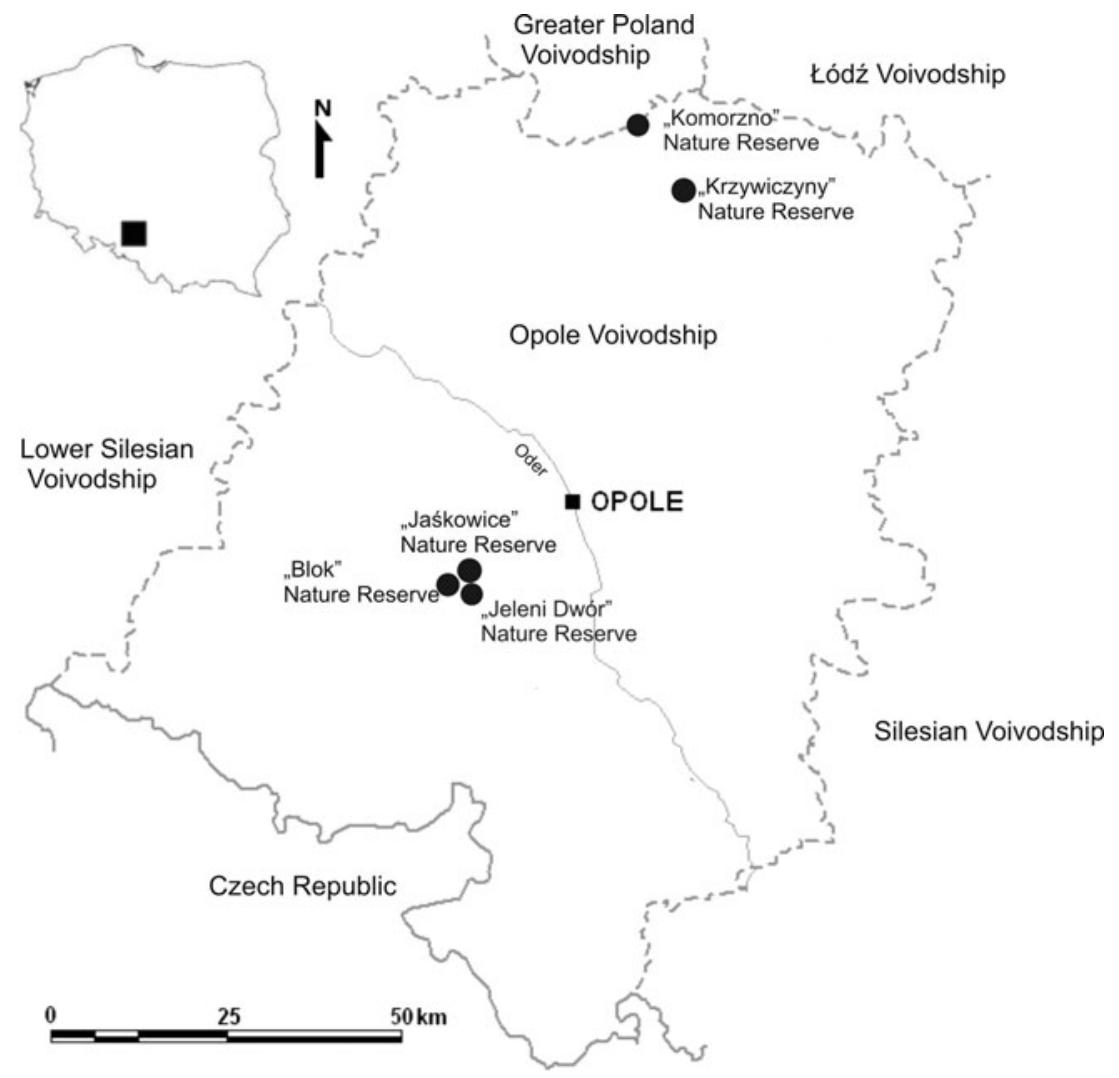

growth sequences were visually cross-dated (Stokes and Smiley 1996) and then statistically checked with COFECHA computer program, which calculates correlations between samples using a 50-year segment length lagged by 25 years, checked at the one-tailed $99 \%$ confidence level (Grissino-Mayer 2001). Ring-width series that were not significantly correlated to the group of samples were removed from the data set and only the best correlated samples created the mean chronologies for each species. Thus, a common climatic signal was emphasized. The curves with anthropogenically conditioned disturbed course (i.e., the occurrence of strong incremental depression or significant increase in tree-ring width), with respect to a common incremental pattern, were eliminated. Also, the sequences with missing rings, as well as the ones from the sites with documented mass insect outbreaks, were excluded from further analysis.

To remove biological growth trends and other potentially non-climatically conditioned fluctuations, an individual tree-ring series were de-trended in a two-step method: using a negative exponential curve followed by a cubic smoothing spline, with $67 \%$ of the length of the series criterion (Cook and Kairiukstis 1990). After averaging by bi-weight robust mean and removing the autocorrelation, the regional residual tree-ring chronologies for the pedunculate oak, sessile oak and Scots pine were created. All de-trending and averaging procedures were conducted using the program ARSTAN (Cook and Holmes 1999).

The extreme year chronologies, which are time series of extraordinary wider or narrower tree-rings caused by extreme climate conditions, were developed according to the probabilistic criterion recommended by the European Climate Assessment \& Dataset, IPCC (2001). The extremes were distinguished taking the criterion of 10 and 90 percentiles. Among different methods of determining the extreme years in dendrochronology, a probabilistic approach was chosen as it takes into account all minima and maxima observed along the curves. In the next step, the constructed extreme years chronologies for the analyzed species were summed in order to emphasize the particularly extreme conditions acting in the same way for all species.

\subsection{Species response to climate}

For comparing tree growth with climate, mean regional temperature and precipitation series were prepared. Four homogeneous and highly correlated data sets from Opole, Wrocław, Katowice and Racibórz were merged. Each chronology was analyzed individually for its relationships with the Silesian records of mean monthly air temperature and monthly precipitation sums, including months from June of the year prior to ring formation to September of the current 
year. All calculations were performed for the same period of 1886-1984. The last 25 years were excluded due to a weak climatic signal determined by moving intervals response function analysis (data not shown in this article).

A procedure of climate variable selection must be carried out before the reconstruction. For this purpose, a correlation function and a response function are estimated. The correlation coefficients in the correlation function are statistically analyzed and when the coefficient exceeds a given $p$ value then its corresponding climatic variable can be used to reconstruct the past climate. In the response function, the magnitudes and the signs of the coefficients of the statistical model B also indicate the importance and signs of the tree-ring response to the calibrated climate variables. The response function in a matrix form can be expressed as follows (Cook and Kairiukstis 1990; Biondi and Waikul 2004):

$\boldsymbol{Y}_{N \times 1}=\left(\mathbf{X}_{N \times M}\right) \boldsymbol{B}_{M \times 1}+\boldsymbol{\varepsilon}_{N \times 1}$

where:

$\mathbf{X}_{N \times M} \quad$ Matrix of predictor variables with $N$ rows (years), $M$ columns (number of climates)

$\boldsymbol{Y}_{N \times 1} \quad N$-element vector of predictant variables ("proxy")

$\boldsymbol{B}_{M \times 1} \quad M$-element vector of coefficients

$\varepsilon_{N \times 1} \quad N$-element vector of misfits

The coefficients of the statistical model B can be estimated by different regression techniques using, for instance, the least square estimation or principal components analysis. Statistical analysis allows users to select statistically significant climate variable or variables, which can be reconstructed. All calculations were carried out in DENDROCLIM2002 software, in which parameters of the response function model are calculated using a multiple regression analysis with principal component analysis (PCA) and bootstrapping (1,000 simulations) techniques (Biondi and Waikul 2004).

\subsection{Calibration and verification procedures}

It is well known that a correlation between tree-ring variations and environmental factors exists and this fact can be used to deduce or reconstruct the past variation in the climate from past variations in "proxy". The procedure to find a statistical relation between the tree-ring growth and the environment is called calibration, which involves the fitting of the statistical model that can be applied to one or more predictors to estimate (reconstruct) one or more predictants. The time interval of 1886-1984 has been split (1886-1936, 1936-1984) and applied to the cross calibration-validation procedure where one set of predictor and predictant data, called the dependent set (half of time interval), is used to estimate the coefficients of the calibration model, while the remaining data, called independent data, is used to validation of the calibration model. The model, after the positive cross calibration-validation procedure, is once again calibrated from the whole time interval and the obtained new model coefficient is used to reconstruct the past climate changes from past variations in tree-ring growths (Cook and Kairiukstis 1990; Bradley 1999).

Climate variables can be reconstructed by a transfer function which is expressed in a matrix form as follows:

$\boldsymbol{Y}_{N \times K}=\left(\mathbf{X}_{N \times M}\right) \boldsymbol{b}_{M \times K}+\boldsymbol{\varepsilon}_{N \times K}$

where:

$\mathbf{X}_{N \times M}$ Matrix of predictor variables with $N$ rows (years), $M$ columns (number of "proxy data" and extreme years index)

$\boldsymbol{Y}_{N \times K} \quad N$-element vector of predictant variables (climate variable)

$\boldsymbol{b}_{M \times K} \quad M$-element vector of coefficients

$\varepsilon_{N \times K} \quad N$-element vector of residuals

In contrast to the response function, the transfer function consists of predictors which are tree-ring growth chronologies that explain the climate elements. In this case, the coefficients are not interpreted, but they are used in climate reconstruction (Cook and Kairiukstis 1990). The coefficients of the transfer function model B can be also estimated by different regression techniques, e.g., least square estimation. The principle of least squares provides a general methodology for fitting straight-line models (or multidimensional plane models) to regression data. In many cases, scatterplots between the real variable and the estimated variables display anything resembling straight-line relationships. Statistical residual analysis can provide a good assessment of the calculated models.

For the multiple linear regression model, the following four model assumptions are made:

- Independence of the random errors.

- Normality of the random errors (normally distributed).

- Homoscedasticity: the random errors have constant variance.

- The random errors have zero mean.

These assumptions are checked by plotting histograms of residual, normality plots of residual and comparing observed values with the calculated ones (Stanisz 2007).

The calibration in dendroclimatology is also associated with certain assumptions that lead to significant restrictions. During the calibration it is assumed that (Cook and Kairiukstis 1990):

- The modelled relation between the tree-ring growth and the environment is stationary in time - what is now also happened in the past. 


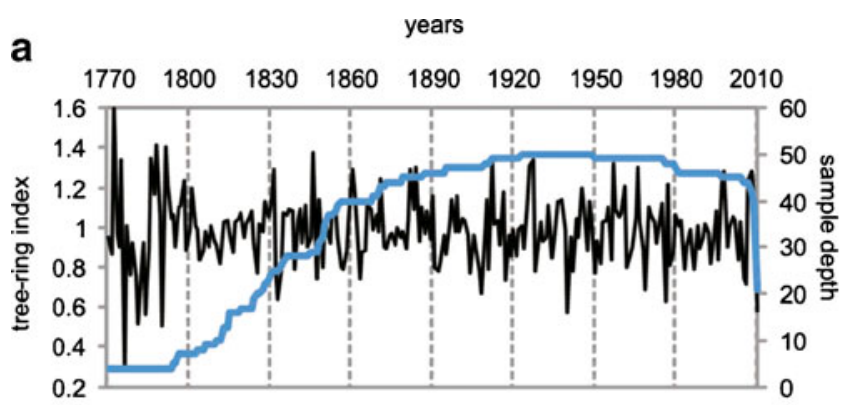

b

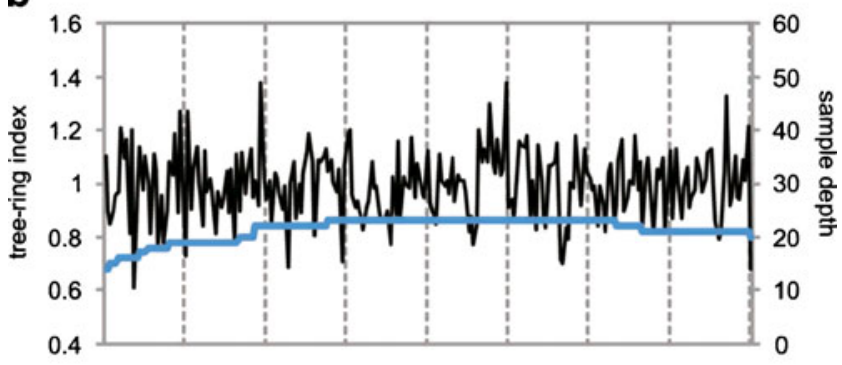

C

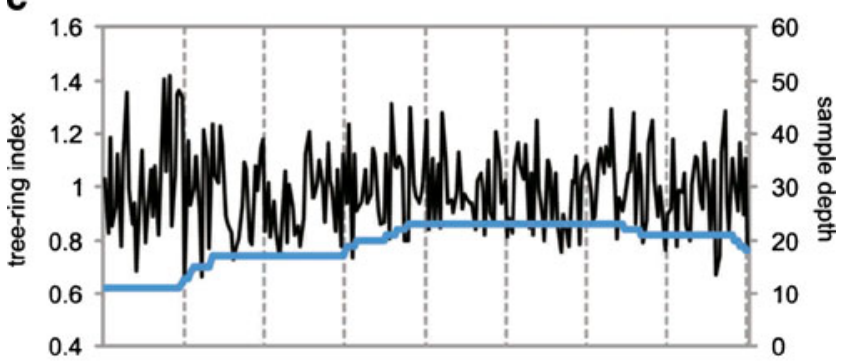

d

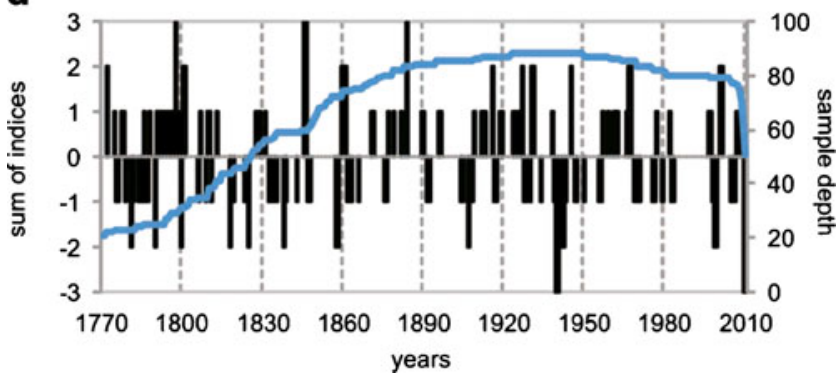

Fig. 2 Tree-ring index (a Scots pine, b pedunculate oak, c sessile oak) and extreme years $(\mathbf{d})$ chronologies and its replication
- Reconstruction of past climate conditions is possible only when the climatic conditions of the present time taken to the calibration are analogous to those of the past.

- Type of relation between variables $\mathrm{x}$ and $\mathrm{y}$ should be searched by application of an appropriate model structure, i.e., for linear models the calibration should be made by regression techniques.

After the calibration and the residual analysis, the validity of the model is checked by calculating correlation coefficient $R$, determination coefficient $R^{2}$, adjusted determination coefficient $R^{2}, F$ value, $p$ value and standard error of estimate (SEE). The verification on independent period is verified by calculated correlation coefficient $r$, correlation coefficient of the first differences $r_{\mathrm{d}}$, reduction of error RE, coefficient of efficiency CE and sign test ST (Fritts 1976; Cook and Kairiukstis 1990; Cook and Pederson 2011).

The estimation of model parameters were carried out using STATISTICA 10.0 software and validation statistics were provided in MATLAB 7.0 programming environment.

\subsection{Reconstruction and regressed temperature scaling}

Reconstruction of the past climate variation is carried out on the basis of the results of the verification procedure which provides an appropriate selection of transfer function model. A well-estimated model is once again calibrated; however, the whole instrumental period is used. When the transfer function coefficients are known, the past climate variation can be estimated from "proxy" index variation.

During the application of multivariate regression (least-squares method), the scaling of the reconstructed climate variables is needed because a variance reduction effect in the regressed model and a decrease of climate magnitudes are observed. The scaling allows users to regain a lost variance. The scaled amplitudes $C_{\mathrm{s}}$ are computed by dividing regressed climate amplitudes $C_{\mathrm{R}}$ by the correlation coefficient $R$ (between "proxy" and climate data from instrumental period) as follows (Esper et al. 2005):

$C_{s}=C_{R} / R$

Table 1 Statistical characteristics of tree-ring width chronologies

\begin{tabular}{|c|c|c|c|c|c|c|c|c|}
\hline species & No. of series & Period ( $>5$ samples) & $\mathrm{MC}$ & GR & $\mathrm{SD}$ & MS & $\mathrm{AC}$ & EPS \\
\hline PISY & 50 & $1770-2010$ & 0.52 & 1.31 & 0.75 & 0.26 & 0.79 & 0.94 \\
\hline QURO & 15 & $1739-2010$ & 0.54 & 1.63 & 0.54 & 0.22 & 0.74 & 0.84 \\
\hline QUPE & 15 & $1769-2010$ & 0.53 & 1.32 & 0.67 & 0.23 & 0.70 & 0.87 \\
\hline
\end{tabular}

$P I S Y$ Scots pine, $Q U R O$ pedunculate oak, $Q U P E$ sessile oak, $M C$ mean interseries correlation values, $G R$ mean growth rate in mm, $S D$ standard deviation of the mean TR measurements, $M S$ mean sensitivity value, $A C$ unfiltered autocorrelation value, $E P S$ expressed population signal 


\section{Results and discussion}

\subsection{Chronology development}

All series of tree-ring index are presented in Fig. 2. The range of the created regional tree-ring chronologies varies from 1739 for the pedunculate oak to 1770 for the Scots pine. Therefore, for the further analysis the common period 1770-2010 was selected. The mean growth rate of the individual series included in the regional chronologies ranged from 1.31 to $1.62 \mathrm{~mm}$ and the standard deviation range was from 0.537 to 0.749 . The mean inter-correlation between single trees was above 0.5 for all chronologies. The mean sensitivity is between 0.221 and 0.256 . The Expressed Population Signal index value exceeded the critical value of 0.85 for all but one chronology. The lowest average value of this index was obtained for the pedunculate oak and it amounted to 0.84 . High values of all the above parameters (Table 1) within the entire data set are believed to indicate a greater climatic influence on the investigated tree growth. In general, the lowest values were obtained for the pedunculate oak, and the highest values for the Scots pine.

The correlations between the chronologies of different tree species, calculated for the period of 241 years, were the highest for the Quercus genus (0.38). The values of correlation coefficient between the pine and oaks were 0.27 (Scots pine-pedunculate oak) and 0.22 (Scots pine-sessile oak).

\subsection{Climate response analysis}

The plots represent the correlation coefficients between "proxy" and monthly temperature (the correlation function) and the response function coefficients corresponding to each climate variable (Fig. 3). Results for precipitation (with lower statistical significance) are not shown in the text. In general, the dendroclimatological calculation allowed us to select winter months (December-March) as the most significant climate variable for the temperature reconstruction (Fig. 3). The significant positive relationship with the previous December and current January was observed for all species, but was the highest for the pedunculate oak. Certain aspects of the dendroclimatological analysis differed among the species. The highest values for both correlation and response function were obtained between the growth of pine and February and March temperatures. The sessile oak showed a strong negative relationship with April and previous August temperature (significant correlation and response coefficients). Warm previous August temperature negatively influenced the growth of all the analyzed species. As shown in Table 2, when
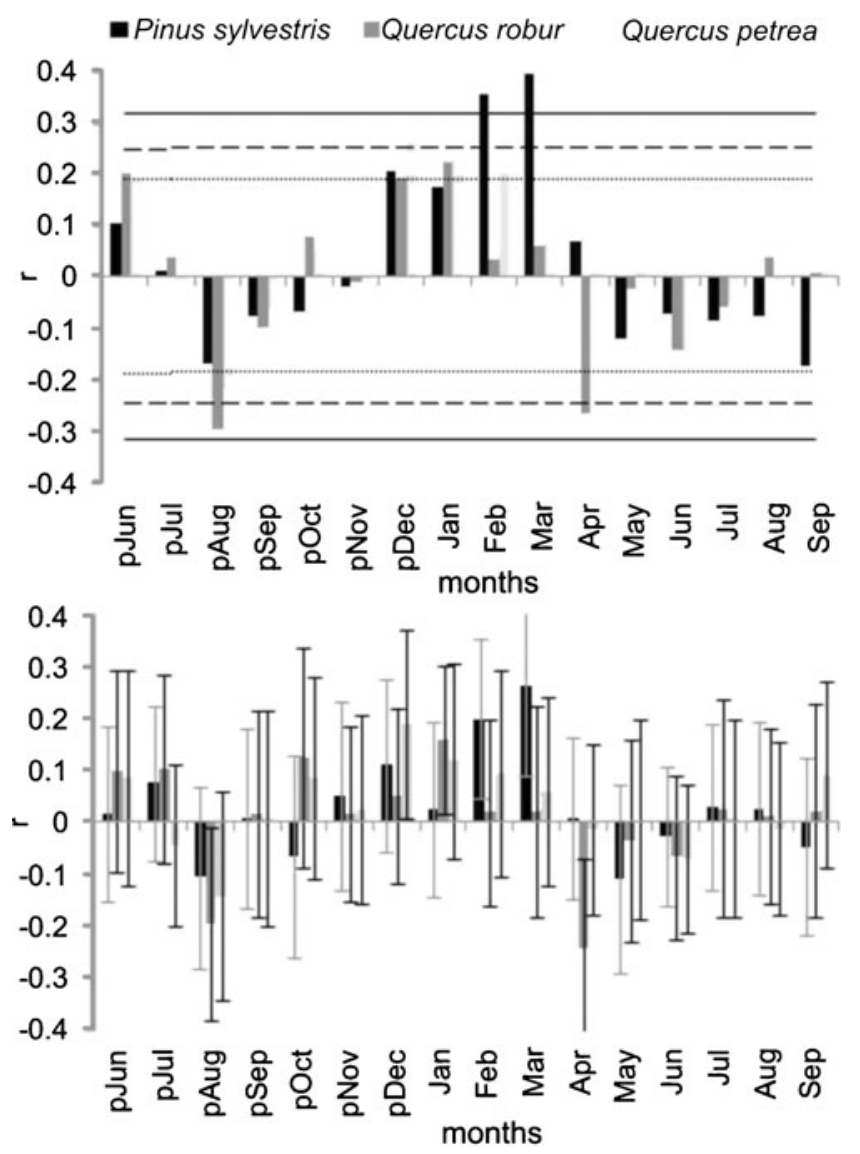

Fig. 3 Correlation function (top) and response function (bottom) between growth of selected species and monthly temperature. Horizontal lines indicate significance levels: $99.9 \%$ (solid line), $99 \%$ (dashed line) and $95 \%$ (dotted line). Bars on the parameters of the response function model indicate $95 \%$ confidence limit for each of the coefficients

chronologies were examined for a seasonal signal, the correlation coefficients were much higher than for single months.

Comparison of the determined extreme years chronology with climate data demonstrates reasonable agreement (Table 3).

Table 2 Selected results from the correlation analysis

\begin{tabular}{lll}
\hline Species & $\begin{array}{l}\text { Period of strongest } \\
\text { relationship }\end{array}$ & $\begin{array}{l}\text { Correlation } \\
\text { coefficient }^{\mathrm{a}}\end{array}$ \\
\hline Scots pine & December-March & 0.45 \\
& March & 0.40 \\
Pedunculate oak & December-January & 0.27 \\
& April & -0.27 \\
Sessile oak & December-January & 0.34 \\
& December & 0.27 \\
\hline
\end{tabular}

Periods with the strongest relationships between tree growth and seasonal/monthly temperature values are shown

${ }^{\text {a }}$ All coefficient are statistically significant at 0.05 level 
Table 3 Years with extreme tree rings in Upper Silesia and their climatic explanation according to documentary evidence (Inglot 1968) and instrumental data (monthly precipitation totals are expressed in percentage of the 1961-1990 reference period, thermal conditions are stated with respect to $1961-1990$ reference period)

\begin{tabular}{|c|c|c|c|}
\hline \multicolumn{2}{|c|}{ Extreme year } & \multirow{2}{*}{$\begin{array}{l}\text { Description of weather or comparison with } \\
\text { meteorological measurements }\end{array}$} & \multirow[t]{2}{*}{ Source } \\
\hline Positive & Negative & & \\
\hline \multirow{7}{*}{$\begin{array}{l}1772 \\
1775\end{array}$} & & No interpretable report & \multirow[t]{7}{*}{ Documentary data } \\
\hline & & Great flood & \\
\hline & 1776 & Dry year & \\
\hline & 1781 & Severe winter, spring frosts & \\
\hline & 1782 & Spring frosts & \\
\hline & 1785 & Severe winter & \\
\hline & 1790 & No interpretable report & \\
\hline 1796 & & Warm winter & \\
\hline 1797 & & Warm winter & \\
\hline \multirow[t]{2}{*}{1798} & & Third, in turn warm winter & \\
\hline & 1800 & Severe winter, drought & \\
\hline \multirow[t]{2}{*}{1807} & & Warm year & \\
\hline & 1811 & Drought & \\
\hline \multirow[t]{3}{*}{1813} & & Wet summer & \\
\hline & 1818 & Severe spring frosts & \\
\hline & 1825 & No interpretable report & \\
\hline 1828 & & Monthly excess of moisture & \\
\hline 1829 & & Wet summer & \\
\hline \multirow[t]{2}{*}{1831} & & Monthly excess of moisture & \\
\hline & 1838 & Severe winter, heavy snowfall, spring frosts & \\
\hline \multirow[t]{2}{*}{1846} & & Warm winter, two monthly excess of moisture, floods & \\
\hline & 1858 & Cold winter, driest year in southern Poland, dry June & \\
\hline 1861 & & Warm February, High rainfall in summer (133\%) & Instrumental data \\
\hline 1871 & & High rainfall in June (203\%) & \\
\hline 1884 & & Very warm winter & \\
\hline 1907 & & Cold winter, dry spring & \\
\hline 1908 & & Dry spring & \\
\hline 1912 & & Warm winter, wet year in Southern Poland & \\
\hline 1916 & & Very warm winter & \\
\hline \multirow[t]{3}{*}{1927} & & Warm winter & \\
\hline & 1940 & Very frosty January and February & \\
\hline & 1942 & Very frosty January and February & \\
\hline 1945 & & Warm February and March & \\
\hline 1966 & & Warm winter, downpours in July & \\
\hline \multirow[t]{5}{*}{1967} & & Warm winter & \\
\hline & 1969 & $\begin{array}{l}\text { Cold winter, winter-spring and summer } \\
\text { drought in Southern Poland }\end{array}$ & \\
\hline & 1970 & Cold winter & \\
\hline & 1976 & Drought in spring & \\
\hline & 1979 & Cold January and February & \\
\hline \multirow[t]{3}{*}{2001} & & Warm winter, July rainfall (246 \%) & \\
\hline & 2006 & Very cold winter & \\
\hline & 2010 & Cold winter & \\
\hline
\end{tabular}

Usually warm winters are responsible for forming very wide rings, while the most likely cause of the narrow rings are late heavy frosts, cold winters and, in some years, also severe droughts.

\subsection{Calibration trials}

In this paper, four dendroclimatic models were selected and tested to find the best equation, in statistical sense, which 
allowed to reconstruct winter temperature past variations. The created models are presented below:

(1) $T_{\mathrm{W}}=b_{0}+b_{1} I_{\mathrm{PISY}}$

(2) $T_{\mathrm{W}}=b_{0}+b_{1} I_{\mathrm{PISY}}+b_{4} E$

(3) $T_{\mathrm{W}}=b_{0}+b_{1} I_{\mathrm{PISY}}+b_{2} I_{\mathrm{QUPE}}+b_{3} I_{\mathrm{QURO}}$

(4) $T_{\mathrm{W}}=b_{0}+b_{1} I_{\mathrm{PISY}}+b_{2} I_{\mathrm{QUPE}}+b_{3} I_{\mathrm{QURO}}+b_{4} E$

where $T_{\mathrm{W}}$ is the mean winter temperature; $b_{0}, b_{1}$ are regression model parameters; $I$ is the tree-ring width index; and $E$ denotes extreme year index; species abbreviations are as in Table 1.

For evaluation of goodness of fit between the actual and estimated winter temperatures, different statistical measures were calculated (Table 4). The first step was the assessment of the calibrated regression model. The principal statistics shows that quite well-fitted models have the best assessment for 1935-1984, e.g., the correlation coefficients exceed the value 0.5 . The other statistics represent acceptable values in both calibration periods. The SEE is at a similar range (1.61-1.66) for all proposed transfer function models and periods. It can also be found that goodness of fitted models increases with an increase of independent variables. The residuals analysis was applied for each model (not shown in this paper). The results showed that residuals (models) have a normal-like distribution and in most cases DW statistics did not unambiguously exclude the existence of autocorrelation in residuals.

Table 4 Summary for calibration/verification statistics of the best transfer functions using combination of the tree-ring width of the Scots pine (PISY), pedunculate oak (QURO) and sessile oak (QUPE) and
Table 5 Correlation matrix of predictors and predictand for model PISY + EXT

\begin{tabular}{lccc}
\hline & PISY & EXT & $T\left({ }^{\circ} \mathrm{C}\right)$ \\
\hline PISY & 1.00 & 0.59 & 0.97 \\
EXT & 0.59 & 1.00 & 0.78 \\
$T\left({ }^{\circ} \mathrm{C}\right)$ & $\mathbf{0 . 9 7}$ & $\mathbf{0 . 7 8}$ & 1.00 \\
\hline
\end{tabular}

Data in bold denote highest correlation

The next step was a transfer function verification procedure. All the proposed models have satisfied the general criteria: $\mathrm{RE}>\mathrm{CE}>0, R>R_{\alpha}, R_{\mathrm{D}}>R_{\mathrm{D} \alpha}$ and passed a sign test. Nevertheless, these models are particularly successful in the early verification period (1886-1935). The statistical parameters obtained for the later verification period (1935-1984) are quite poor, especially the RE and CE statistics, which test whether the model provides a more skillful estimate than the mean climatology of the calibration and verification periods. The average coefficient of efficiency (CE) is slightly below zero which indicates the diminished confidence. For the verification periods correlation coefficients for all composite models were slightly lower than for the calibration periods. The exception is a simple linear model for the Scots pine, which has the most stable relationship in both periods ( 0.34 and 0.51 , respectively).

extreme years chronology $(E)$ as predictors of mean winter temperature for the sub-periods of 1886-1936 and 1936-1984

\begin{tabular}{|c|c|c|c|c|c|c|c|c|c|c|c|c|c|c|}
\hline \multirow[t]{2}{*}{ Predictors } & \multicolumn{7}{|c|}{ Calibration 1886-1936 } & \multicolumn{7}{|c|}{ Verification 1936-1984 } \\
\hline & $R$ & $R^{2}$ & $\mathrm{aR}^{2}$ & $F$ & $p$ & SEE & DW & $R$ & $R_{\alpha}$ & $R_{\mathrm{D}}$ & $R_{\mathrm{D} \alpha}$ & $\mathrm{RE}$ & $\mathrm{CE}$ & ST \\
\hline PISY & 0.34 & 0.12 & 0.11 & 6.62 & 0.01 & 1.61 & 1.88 & 0.34 & 0.28 & 0.36 & 0.28 & 0.06 & 0.02 & $30 / 18$ \\
\hline $\mathrm{PISY}+\mathrm{E}$ & 0.35 & 0.13 & 0.09 & 3.29 & 0.05 & 1.62 & 1.86 & 0.31 & 0.28 & 0.26 & 0.28 & 0.04 & -0.01 & $27 / 18$ \\
\hline PISY + QURO + QUPE & 0.38 & 0.14 & 0.09 & 2.54 & 0.06 & 1.62 & 2.03 & 0.34 & 0.28 & 0.31 & 0.28 & 0.04 & -0.01 & $29 / 18$ \\
\hline \multirow[t]{3}{*}{$\mathrm{PISY}+\mathrm{QURO}+\mathrm{QUPE}+\mathrm{E}$} & 0.40 & 0.16 & 0.08 & 2.08 & 0.09 & 1.63 & 1.98 & 0.32 & 0.28 & 0.28 & 0.28 & 0.03 & -0.01 & $29 / 18$ \\
\hline & \multicolumn{7}{|c|}{ Calibration 1936-1984 } & \multicolumn{7}{|c|}{ Verification 1886-1936 } \\
\hline & $R$ & $R^{2}$ & $\mathrm{aR}^{2}$ & $F$ & $p$ & SEE & DW & $R$ & $R_{\alpha}$ & $R_{\mathrm{D}}$ & $R_{\mathrm{D} \alpha}$ & $\mathrm{RE}$ & $\mathrm{CE}$ & $\mathrm{ST}$ \\
\hline PISY & 0.51 & 0.26 & 0.24 & 16.80 & 0.00 & 1.66 & 1.39 & 0.51 & 0.28 & 0.59 & 0.28 & 0.21 & 0.17 & $31 / 18$ \\
\hline PISY + E & 0.55 & 0.30 & 0.27 & 10.20 & 0.00 & 1.63 & 1.40 & 0.48 & 0.28 & 0.57 & 0.28 & 0.19 & 0.15 & $31 / 18$ \\
\hline PISY + QURO + QUPE & 0.56 & 0.32 & 0.27 & 7.10 & 0.00 & 1.63 & 1.48 & 0.49 & 0.28 & 0.56 & 0.28 & 0.22 & 0.19 & $31 / 18$ \\
\hline \multirow[t]{2}{*}{$\mathrm{PISY}+\mathrm{QURO}+\mathrm{QUPE}+\mathrm{E}$} & 0.57 & 0.33 & 0.26 & 5.36 & 0.00 & 1.64 & 1.46 & 0.41 & 0.28 & 0.47 & 0.28 & 0.16 & 0.13 & $25 / 18$ \\
\hline & \multicolumn{7}{|c|}{ Calibration 1886-1984 } & & & & & & & \\
\hline PISY & 0.43 & 0.18 & 0.17 & 21.93 & 0.00 & 1.65 & 1.60 & & & & & & & \\
\hline $\mathrm{PISY}+\mathrm{E}$ & 0.45 & 0.20 & 0.18 & 11.85 & 0.00 & 1.64 & 1.65 & & & & & & & \\
\hline PISY + QURO + QUPE & 0.46 & 0.21 & 0.19 & 8.60 & 0.00 & 1.64 & 1.68 & & & & & & & \\
\hline $\mathrm{PISY}+\mathrm{QURO}+\mathrm{QUPE}+\mathrm{E}$ & 0.47 & 0.21 & 0.18 & 6.41 & 0.00 & 1.64 & 1.69 & & & & & & & \\
\hline
\end{tabular}

$R$ correlation coefficient, $R^{2}$ determination coefficient, $a R^{2}$ adjusted determination coefficient, $F$ Fisher statistics, $p$ probability value $(0.00$ value means $p<0.005), S E E$ standard error of estimate, $D W$ Durbin-Watson statistics, $R_{\alpha}$ critical value for $R(0.05$ significant level $), R_{D}$ first differences correlation coefficient, $R_{D \alpha}$ critical value for $R_{\mathrm{D}}(0.05$ significant level $), R E$ average reduction of error, $C E$ average coefficient of efficiency, $S T$ sign test 
Table 6 Correlation matrix of predictors and predictand for model PISY + QURO + QUPE

\begin{tabular}{lllll}
\hline & PISY & QURO & QUPE & $T\left({ }^{\circ} \mathrm{C}\right)$ \\
\hline PISY & 1.00 & 0.27 & 0.22 & 0.93 \\
QURO & 0.27 & 1.00 & 0.39 & 0.36 \\
QUPE & 0.22 & $\mathbf{0 . 3 9}$ & 1.00 & 0.57 \\
$T\left({ }^{\circ} \mathrm{C}\right)$ & $\mathbf{0 . 9 3}$ & 0.36 & $\mathbf{0 . 5 7}$ & 1.00 \\
\hline
\end{tabular}

Data in bold denote highest correlation

Comparing calibration results (simple vs. complex models) it was found out that an additional parameter $\mathrm{E}$ or/and combination of species can improve statistical assessment of a model, what is a result of an increase of dependent variables in a model which corrects the fitting in general. However, verification showed inverse order, the simple model has the best assessment, but other models also have acceptable assessment values. Good results for both types of calculation were obtained for the third model, which includes three different species (Table 4).

According to the classical model of linear regression, predictors in the model should be correlated with the predictand and uncorrelated with each other. But the actual data are always correlated to some extent, so regressors are collinear that show correlation matrices (Tables 5, 6 and 7).

Multicollinearity does not adversely affect the regression equation if the purpose of research is only to predict the dependent variable from a set of predictor variables. However, estimation of the contributions of individual predictors is relevant. Thus, variance inflation factors (VIF) for each predictor (Table 8 ) have been calculated. VIF indicates how many times the variance of the estimator increased and in other words how much the variance of the coefficient estimate is being inflated by multicollinearity.

The last step before the climate reconstruction was a repeated calibration of the transfer function but the calculations were carried out over the whole instrumental period of 1886-1984. The statistical assessment of the calibration is compared in Table 4 and the results of the residuals analysis for the selected models are plotted in Figs. 4, 5, 6 and 7.

In general, the residuals analysis of the chosen models confirms the multiple linear regression model assumptions. The residuals distributions and normality plots suggest that residuals have a normal distribution. Each plot presents
Table 8 Variance inflation factors (VIF) for each predictor

$R_{j}^{2}$ is determination coefficient calculated for $j$ th predictor treated as a dependent variable

\begin{tabular}{lll}
\hline & $R_{j}^{2}$ & VIF \\
\hline PISY & 0.38 & 1.61 \\
QURO & 0.37 & 1.59 \\
QUPE & 0.40 & 1.67 \\
EXT & 0.68 & 3.12 \\
\hline
\end{tabular}

histograms of residuals with the Gaussian-like distribution and normality plot similar to a straight line.

The transfer functions to reconstruct past mean winter temperature variation $T_{\mathrm{W}}$ depending on "proxy" data $I_{i}$ and extreme index $E$ can be expressed as follows:

(1) $T_{\mathrm{W}}=-4.86+4.99 I_{\mathrm{PISY}}$

(2) $T_{\mathrm{W}}=-3.86+3.98 I_{\mathrm{PISY}}+0.31 E$

(3) $T_{\mathrm{W}}=-6.70+4.20 I_{\mathrm{PISY}}+2.72 I_{\mathrm{QUPE}}-0.11 I_{\mathrm{QURO}}$

(4) $T_{\mathrm{W}}=-6.14+4.04 I_{\mathrm{PISY}}+2.47 I_{\mathrm{QUPE}}-0.25 I_{\mathrm{QURO}}+0.1 E$

\subsection{Assessment of potential for climate reconstruction}

Apart from the slightly better statistical assessment and higher values of the correlation with the observed data, the winter season temperature reconstruction made by regression using a combination of species or combination of species and additional extreme index allows for better representation of extreme values of temperature (Table 9). It is especially well visible in the years with particularly cold winters $(1893,1908,1940-1943,1947,1956,1963)$ and warm winters $(1916,1927,1938,2001)$. Furthermore, these models improve the results in the years in which a simple model reconstructs both values and signs of temperatures incorrectly. Such a situation can be observed in the example of 1919, when the simple model reconstructs the temperature drop, while the complex model reproduces the increase in temperature observed in reality (Table 9). Obviously, there are periods in which there is a poorer fit, such as 1990 or 1997-1999. This is due to the significant influence of pluvial conditions, as the rainfall of the summer season is the second important factor in the formation of the radial increment of pine and oak trees in the lowland areas in Poland (Zielski 1997; Wilczyński 1999; Cedro 2004). Exceptional precipitation conditions may be imposed on the influence of temperature or modify it in some years.
Table 7 Correlation matrix of predictors and predictand for model PISY + QURO + QUPE + EXT correlation

\begin{tabular}{llllll}
\hline & PISY & QURO & QUPE & EXT & $T\left({ }^{\circ} \mathrm{C}\right)$ \\
\hline PISY & 1.00 & 0.27 & 0.22 & 0.59 & 0.93 \\
QURO & 0.27 & 1.00 & 0.39 & 0.60 & 0.36 \\
QUPE & 0.22 & 0.39 & 1.00 & 0.61 & 0.57 \\
EXT & 0.59 & $\mathbf{0 . 6 0}$ & $\mathbf{0 . 6 1}$ & 1.00 & 0.75 \\
$T\left({ }^{\circ} \mathrm{C}\right)$ & $\mathbf{0 . 9 3}$ & 0.36 & 0.57 & $\mathbf{0 . 7 5}$ & 1.00 \\
\hline
\end{tabular}


Fig. 4 Residuals distribution (a) and normality plot (b) for simple mode (pine)

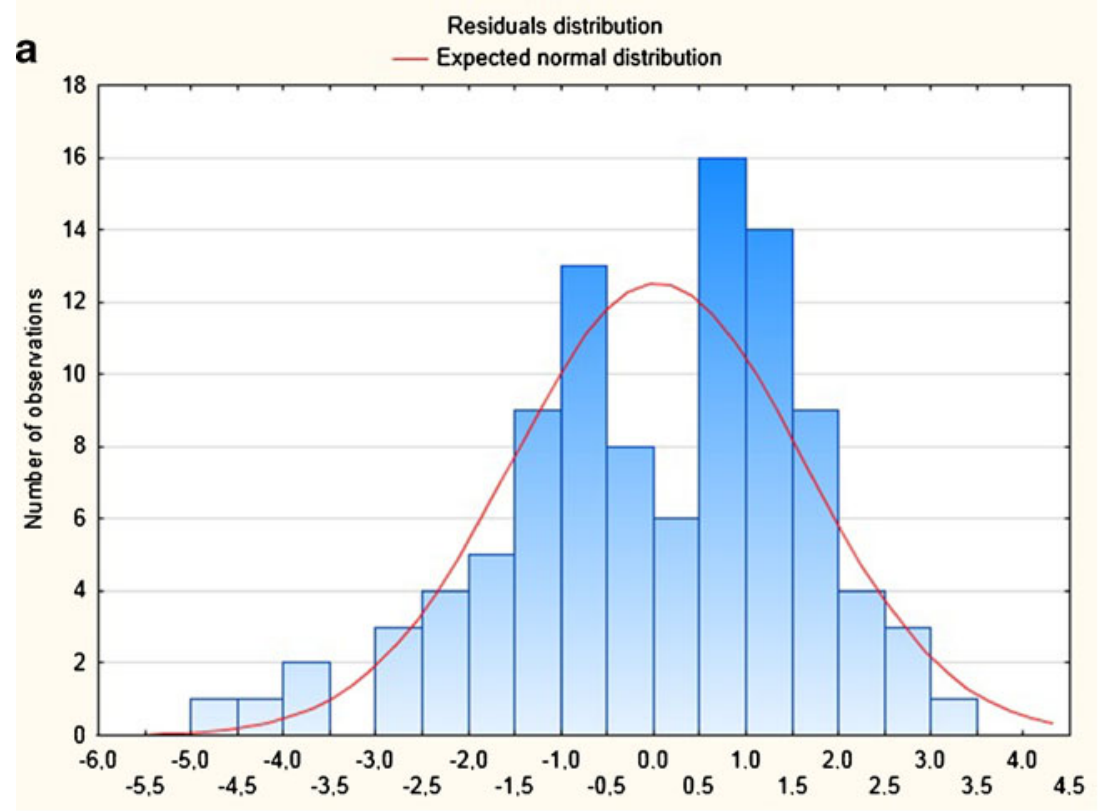

b

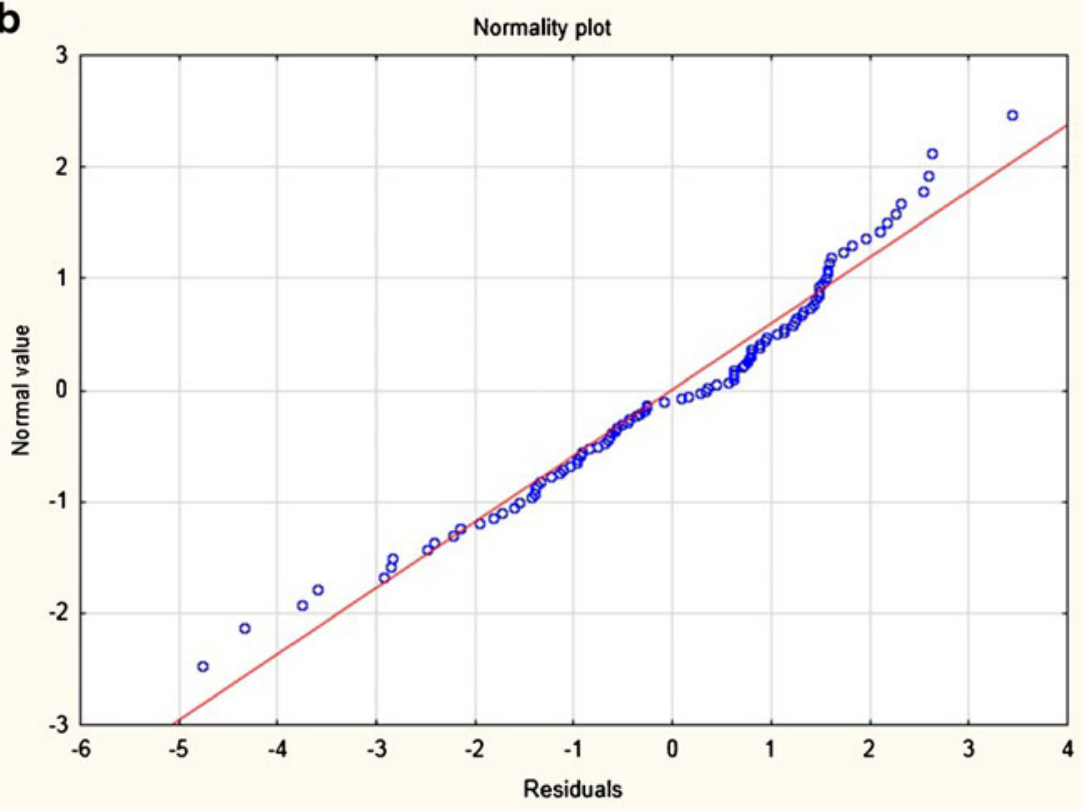

The impact of rainfall during summer months is especially significant in the years with extreme values of this meteorological element (see Table 3).

The comparison of reconstructed values shown in Table 9 indicates that temperature amplitudes obtained from linear regression and after scaling differ significantly. The results presented in the table suggest that all models beyond the simple one, better reflect the measured values. In most cases, the closest match to the measured temperature was obtained for the complex models. The results of reconstruction by the simple regression method remain below that of the target instrumental data.

In general, the statistical differences between the proposed transfer functions are not very large and it was quite difficult to indicate the best model. The general results presented above indicate the selection of the multispecies model for reconstruction. Even though the model with an additional parameter $\mathrm{E}$ gives promising results in the years with extreme temperatures (usually reconstructed with a less extreme character), which may be reproduced more precisely, it gives worse statistical evaluation.

The reconstruction of winter temperature back to 1770 is shown as actual temperature values expressed in degrees Celsius (after scaling against instrumental measurements) (Fig. 8). Performed dendroclimatological reconstruction of winter temperature was compared with the information on the occurrence of extremely cold or warm winters in the following decades. Historical data related to weather 
Fig. 5 Residuals distribution (a) and normality plot (b) for extended simple mode (pine + extreme index)

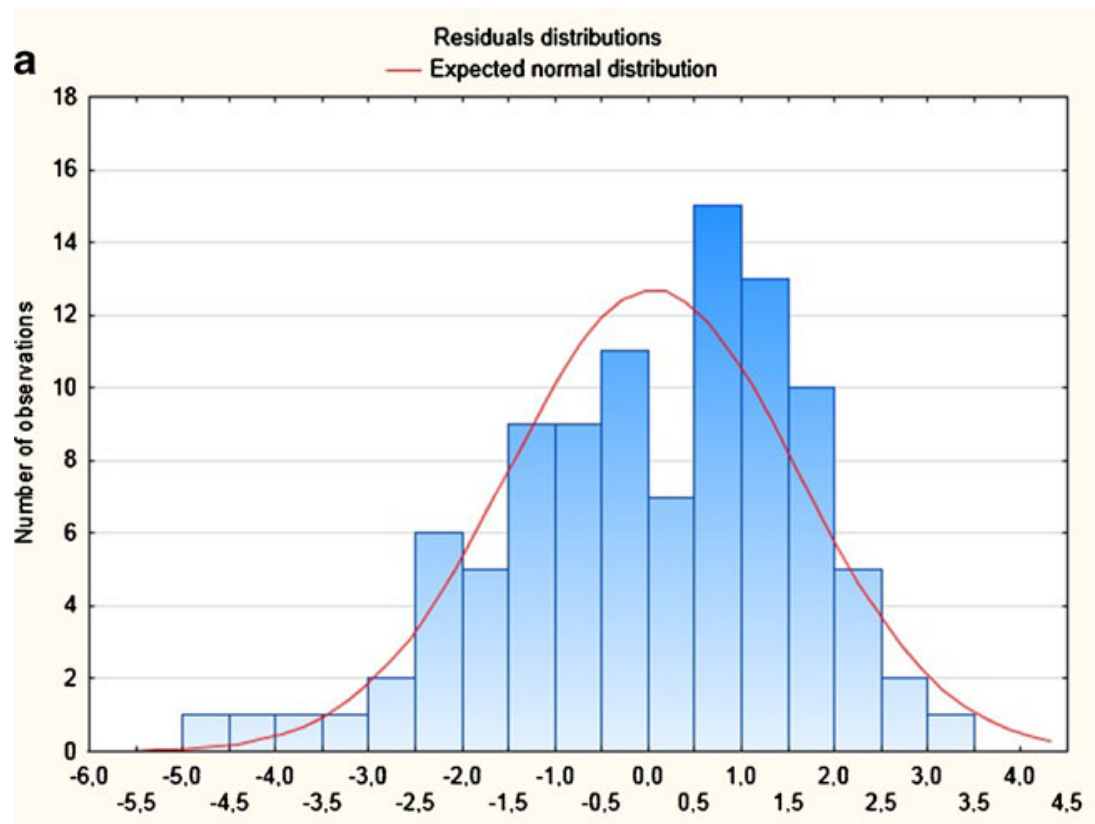

b

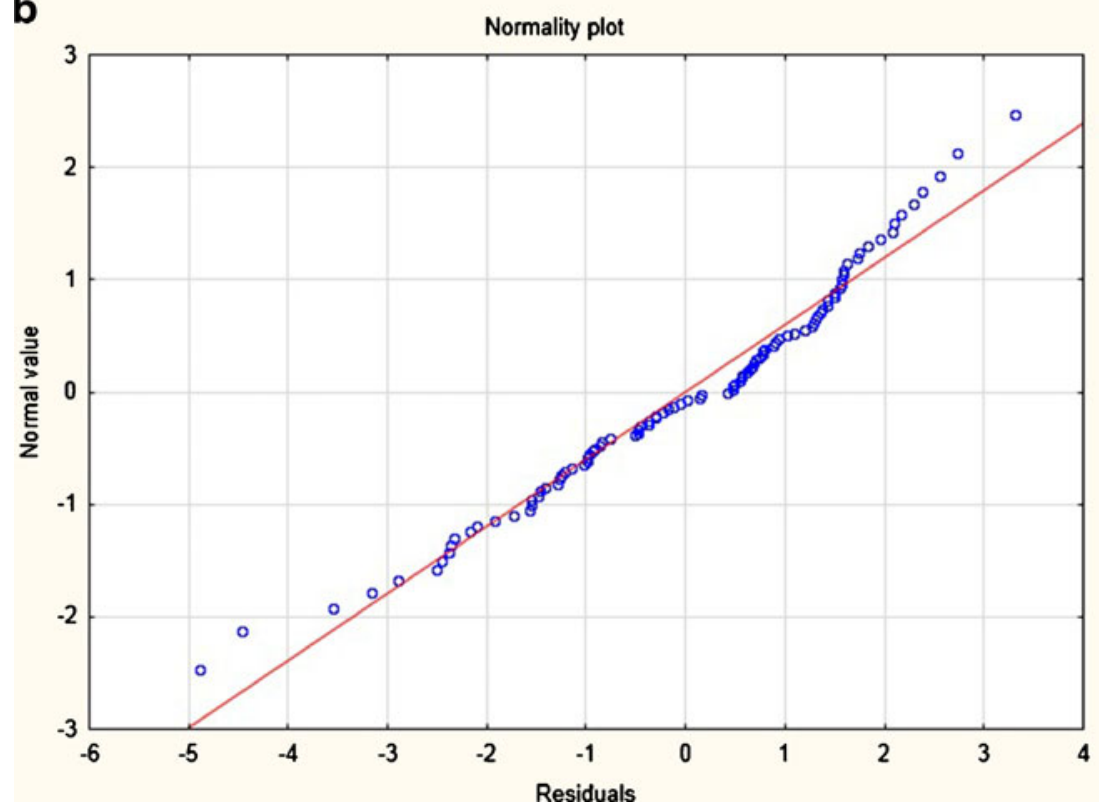

conditions of Silesia, descriptions of the periods of severe or mild winters, were selected from a number of studies containing historical records for the Polish territory (after Namaczyńska 1937; Inglot 1968; Rojecki 1965). In the instrumental period the years with extremely cold or warm winters were determined according to probabilistic criterion (10 and 90 percentile). The compiled historical and instrumental data concerning the periods of extremely cold and warm winters are consistent with the proposed dendroclimatological reconstruction and confirm its reconstruction capabilities in the independent period.

The smooth line shows 10-year filtered values to emphasize the decadal scale fluctuations. The analysis of reconstructed temperature allows for determinations of the coldest decades: 1775-1785, 1830-1840, 1870-1880, 1900-1910, 1935-1945, 1980-1990, and the warmest decades: 1790-1800, 1880-1890, 1910-1930, 1990-2000. Besides, a significant decrease of the reconstruction curve in the period 1800-1830 can be observed. This well pronounced temperature decline is referred to as the Dalton Minimum - a cold period at the turn of the 18th and 19th centuries where several important climate forces (variation in solar irradiance, active volcanism, initial rise in the concentration of carbon dioxide) had an influence on the temperature deviations (Eddy 1976; Wagner and Zorita 2005). 
Fig. 6 Residuals distribution (a) and normality plot (b) for multispecies model (pine + oaks)

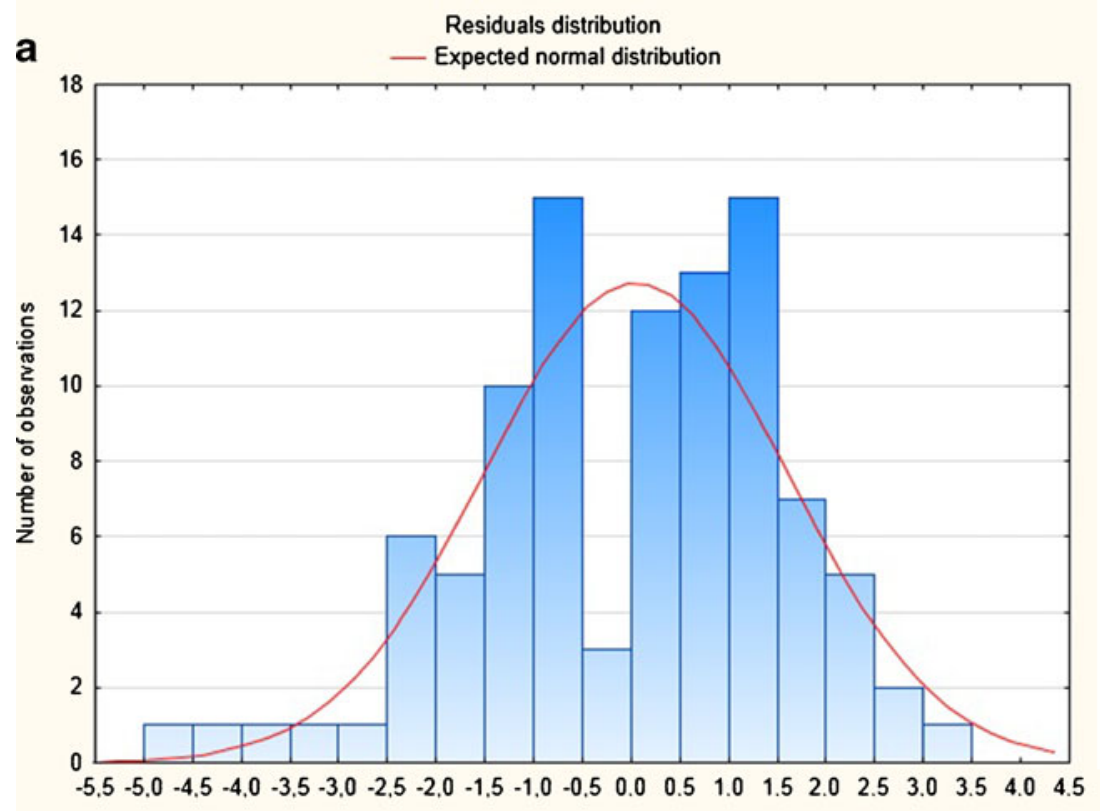

b

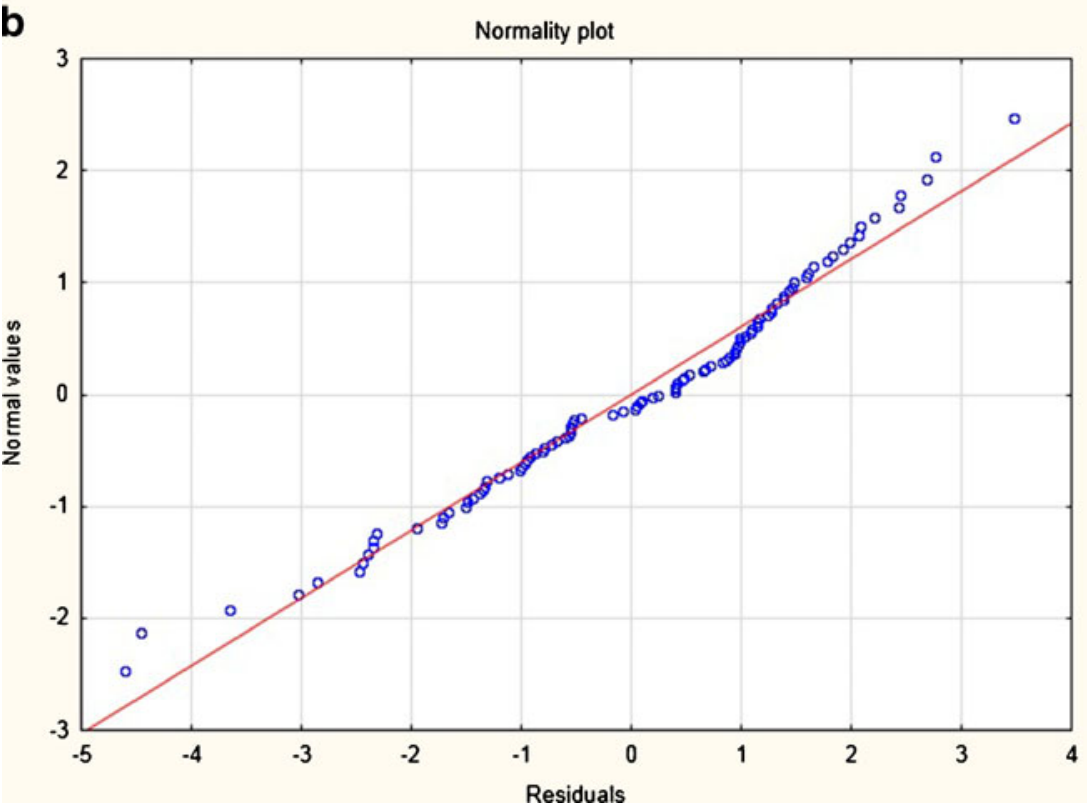

The obtained results are comparable with other winter temperature reconstructions performed for Poland, especially in terms of using the Scots pine as a predictor for winter (February and March) air temperature reconstruction (Cedro 2004; Krapiec et al. 2009; Szychowska-Krapiec 2010; Koprowski et al. 2012) and distinction of the Dalton Minimum cold period (Szychowska-Krapiec 2010; Krapiec et al. 2009). Also, cold episode in the years 1860-1880 appears in the course of the winter temperature reconstructions for northern Poland (Krapiec et al. 2009).

Comparing the course of regional reconstruction with European and global instrumental data (Fig. 9), one can find the largest convergence at the turn of 18th and 19th century, expressed as a deep temperature drop in both regional and continental scale, in the period know as a Dalton Minimum. Cold winters in the first decade of the 20th century and in the years: 1875-1880, 1890, 1920, 1980 are consistent with European data. Warmer periods - especially $1790-1800$, 1820-1830, 1890-1900 and 1990-2000 - are also characterized by a certain similarity.

It should be emphasized that the presented reconstruction reflects both a general course of the temperature and the extreme thermal conditions quite well, which might be an interesting contribution, as the previous reconstruction of winter temperature conditions (conventional regression based on single species models) did not allow to obtain the correct results during the occurrence of short-term extreme weather conditions (e.g., 1940, 1946, 1951, 1988 in 
Fig. 7 Residuals distribution (a) and normality plot (b) for extended multispecies model (pine + oaks + extreme index)
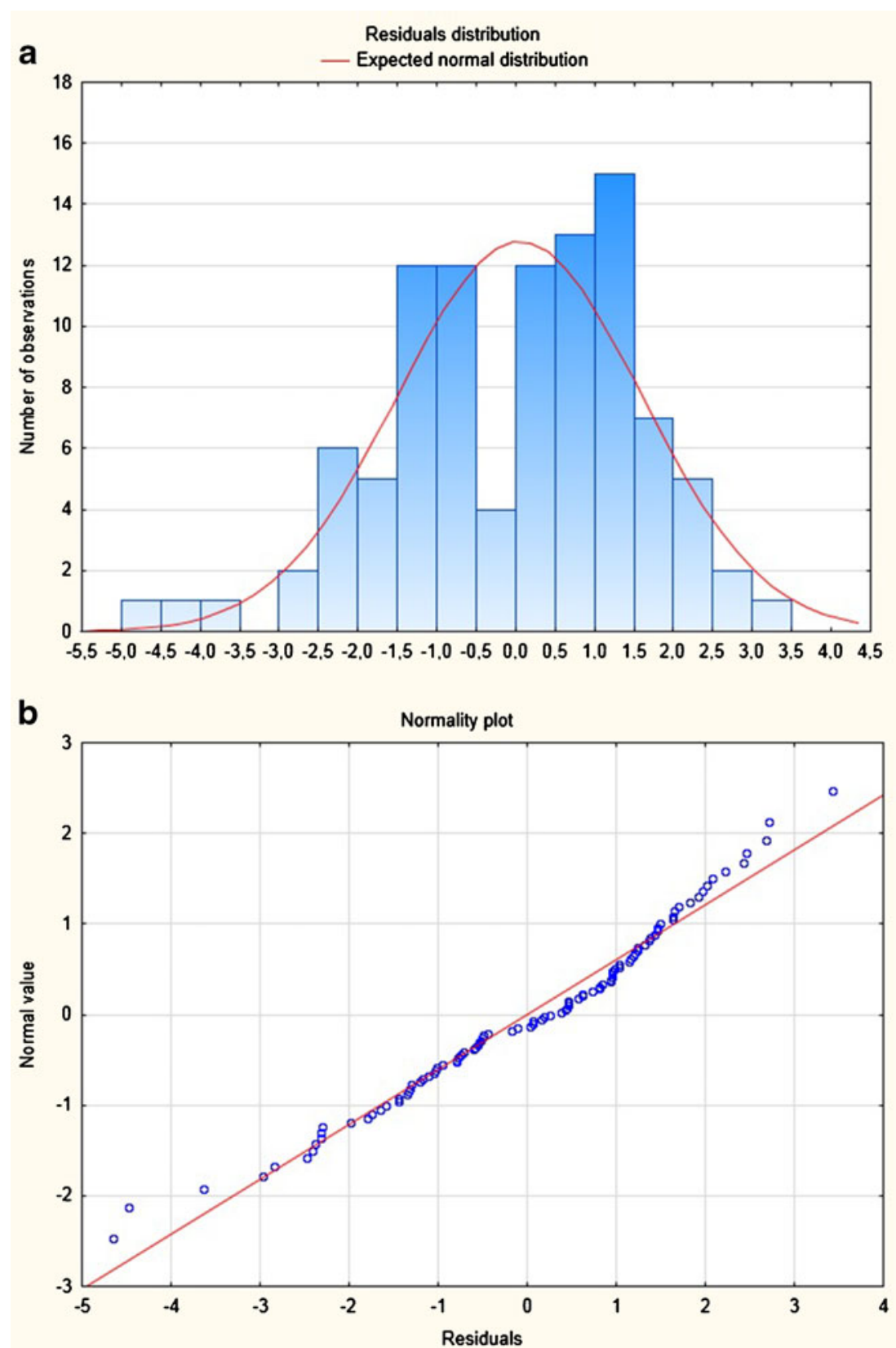

Krapiec et al. 2009) and this underestimation was usually supplemented by a separate pointer years analysis (Cedro 2004; Szychowska-Krapiec 2010; Koprowski et al. 2012).

A number of recent dendroclimatological investigation have analyzed winter (e.g., Popa and Cheval 2007; Zhu et al. 2009) or summer mean temperature (e.g., Li et al. 2011), maximum and minimum temperature (Wilson and Luckman 2002) and extremes (Battipaglia et al. 2010), based on individual single proxy or the so called all-species chronology (multispecies chronologies as the arithmetic mean of these records) (e.g., Büntgen et al. 2005; Feliksik and Wilczyński 2009). In this study, we give an insight into the use of composite models, simultaneously using a number of temperature sensitive species and an additional extreme index. Although the statistics for each model did not differ much from each other, the best results were obtained using combination of species. This result confirmed the idea and validity of using multispecies models previously proposed by Yadav et al. (1997) or GarciáSuárez et al. (2009).

\section{Conclusions}

(1) The presented results show that the temperature of winter months seems to be one of the most important factors influencing the tree-ring formation in the Upper Silesia region. This dependence is species-specific: 
Table 9 Selected years of minimum, maximum and average values of measured mean winter temperature in comparison to temperature reconstructed by different methods

\begin{tabular}{|c|c|c|c|c|c|c|c|c|c|}
\hline \multirow[t]{2}{*}{ Year } & \multirow{2}{*}{$\begin{array}{l}\text { Temperature } \\
\text { measured } \\
\left({ }^{\circ} \mathrm{C}\right)\end{array}$} & \multicolumn{4}{|c|}{ Temperature reconstructed using regression $\left({ }^{\circ} \mathrm{C}\right)$} & \multicolumn{4}{|c|}{ Temperature reconstructed and scaled $\left({ }^{\circ} \mathrm{C}\right)$} \\
\hline & & pin & $\operatorname{pin}+\mathrm{E}$ & pin + rob + pet & pin + rob + pet $+E$ & pin & $\operatorname{pin}+\mathrm{E}$ & pin + rob + pet & pin + rob + pet $+E$ \\
\hline 1963 & -5.32 & -0.55 & -0.43 & -0.72 & -0.66 & -1.28 & -0.96 & -1.55 & -1.43 \\
\hline 1940 & -4.86 & -2.01 & -2.52 & -2.46 & -2.54 & -4.68 & -5.66 & -5.33 & -5.49 \\
\hline 1947 & -4.18 & -0.42 & -0.63 & -0.53 & -0.55 & -0.98 & -1.42 & -1.15 & -1.20 \\
\hline 1942 & -3.81 & -0.94 & -1.35 & -1.33 & -1.39 & -2.18 & -3.02 & -2.88 & $-\mathbf{3 . 0 0}$ \\
\hline 1956 & -2.42 & -0.69 & -0.85 & -1.07 & -1.09 & -1.62 & -1.91 & -2.32 & -2.37 \\
\hline 1969 & -2.37 & -1.43 & -1.44 & -0.99 & -1.07 & -3.33 & -3.23 & -2.15 & -2.31 \\
\hline 1893 & -2.12 & -0.71 & -0.56 & -0.99 & -0.91 & -1.66 & -1.26 & -2.13 & -1.96 \\
\hline 1953 & -0.23 & 0.29 & 0.24 & -0.15 & -0.11 & 0.67 & 0.54 & -0.33 & -0.24 \\
\hline 1896 & 0.38 & 0.23 & 0.50 & 0.14 & 0.18 & 0.52 & 1.12 & 0.31 & 0.39 \\
\hline 1991 & 0.43 & 0.23 & 0.19 & 0.29 & 0.26 & 0.54 & 0.43 & 0.63 & 0.56 \\
\hline 1946 & 1.04 & 0.69 & 0.56 & 0.62 & 0.57 & 1.60 & 1.26 & 1.33 & 1.24 \\
\hline 1919 & 1.59 & -0.58 & -0.14 & 0.55 & 0.56 & -1.35 & -0.32 & 1.20 & 1.21 \\
\hline 1889 & 2.33 & 0.94 & 0.75 & 1.06 & 1.01 & 2.18 & 1.70 & 2.29 & 2.18 \\
\hline 2008 & 2.60 & 1.54 & 1.53 & 1.35 & 1.39 & 3.58 & 3.47 & 2.92 & 3.01 \\
\hline 1916 & 3.29 & 1.04 & 1.45 & 1.31 & 1.37 & 2.41 & 3.27 & 2.83 & 2.97 \\
\hline 2007 & 4.15 & 1.32 & 1.37 & 1.35 & 1.35 & 3.08 & 3.08 & 2.93 & 3.91 \\
\hline
\end{tabular}

Values in bold indicate the value closest to the measured temperature

oaks are most sensitive for December and January mean temperature, while for the pine the correlation coefficients were the highest when calculated for February and March temperature. Climatic explanation of the extreme years in Upper Silesia, according to documentary evidence and instrumental data, confirms the strong influence of thermal conditions of winter on tree-ring formation.

(2) A combination of temperature sensitive species and an additional extreme index in regression can improve the reconstruction, with an emphasis on more reliable reconstruction of extreme values. Despite the differences in the statistics are not very large, adding even one of these parameters we can expect better results. This observation may have a practical application in the future if further research confirms it.

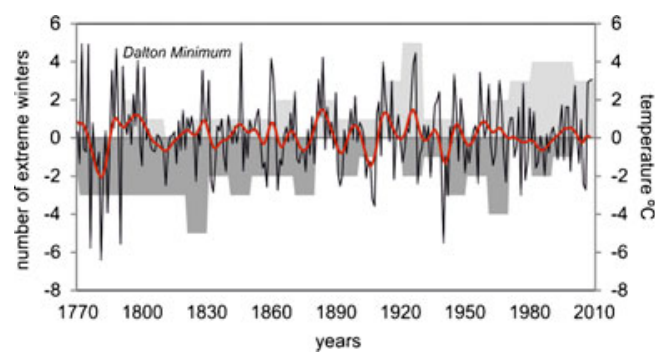

Fig. 8 Annually resolved winter (DJFM) temperature reconstruction over the 1770-2010 period, with the bold line representing a 10-year low-pass filter. Grey horizontal bars indicate the number of extreme cold (dark grey) and warm (light grey) winters per decade based on historical archives and instrumental observations
(3) The best results were obtained using the multispecies model and scaling the results of the regression, which eliminates the reduction in variance in the regression model and allows for precise reconstruction of actual values of temperature.

(4) Although Upper Silesia is traditionally regarded as the region with the significant transformation of the natural environment, with an appropriate site selection dendroclimatological analyzes are possible. Promising calibration/verification results suggest that, through the application of long-term composite chronologies a

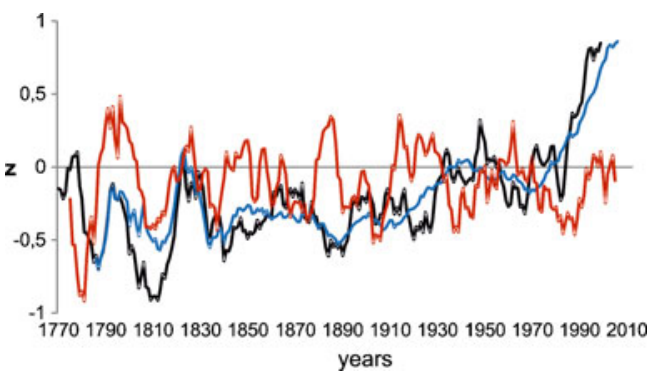

Fig. 9 Comparison of the winter temperature variation derived from: regional dendroclimatic reconstruction of Upper Silesia; red line, four European records (Central England, De Bilt, Berlin and Uppsala); black line, northern hemisphere records (CRUTEM3 instrumental data according to Jones et al. 2012); blue line, during the last 240 years. Data represent temperature anomaly with respect to the reference period 1961-1990. All series have been smoothed with 11-year average 
detailed study of the climate variability in recent centuries can be provided.

\begin{abstract}
Acknowledgements Sampling in the nature reserves was made possible by permission of the Regional Nature Conservator in Opole. This work was funded by the National Science Center as research project No. N306 139638 (2010-2012) and by the Faculty of Earth Science University of Silesia, Poland.
\end{abstract}

Open Access This article is distributed under the terms of the Creative Commons Attribution License which permits any use, distribution, and reproduction in any medium, provided the original author(s) and the source are credited.

\section{References}

Atlas Śląska Dolnego i Opolskiego (2008) Pracownia Atlasu Dolnego Śląska. Uniwersytetu Wrocławskiego, Wrocław

Barber VA, Juday GP, Finney BP, Wilmking M (2004) Reconstruction of summer temperatures in interior Alaska from tree-ring proxies: evidence for changing synoptic climate regimes. Clim Chang 63:91-120

Battipaglia G, Frank D, Büntgen U, Dobrovolny P, Brazdil R, Pfister C, Esper J (2010) Five centuries of Central European temperature extremes reconstructed from tree-ring density and documentary evidence. Global Planet Change 72:182-191

Biondi F, Waikul K (2004) DENDROCLIM2002: a C++ program for statistical calibration of climate signals in tree-ring chronologies. Comput Geosci UK 30:303-311

Boryczka J, Stopa-Boryczka M, Pietras K, Bijak S, Błażek E, Skrzypczuk J (2005) Atlas współzależności parametrów meteorologicznych i geograficznych w Polsce. T. XIX: Cechy termiczne klimatu Europy. Wydawnictwo WGiSR, Warszawa

Bradley RS (1999) Paleoclimatology. Reconstructing climates of the quaternary. International Geophysics Series, vol 64, 2nd edn. Academic Press, New York

Bronisz A, Sz B, Bronisz K, Zasada M (2012) Climate influence on radial increment of oak (Quercus sp.) in central Poland. Geochronometria 39(4):276-284. doi:10.2478/s13386-012-0011-7

Büntgen U, Esper J, Frank DC, Nicolussi K, Schmidhalter M (2005) A 1052-year tree-ring proxy for Alpine summer temperatures. Clim Dynam 25:141-153

Büntgen U, Frank DC, Kaczka RJ, Verstege A, Zwijacz-Kozica T, Esper J (2007) Growth/climate response of a multi-species treering network in the Western Carpathian Tatra Mountains, Poland and Slovakia. Tree Physiol 27:689-702

Cedro A (2004) Zmiany klimatyczne na Pomorzu Zachodnim w świetle analizy przyrostów rocznych sosny zwyczajnej, daglezji zielonej i rodzimych gatunków dębów. Wydawnictwo In Plus, Szczecin

Cedro A (2007) Tree-ring chronologies of Downy oak (Quercus pubescens), Pedunculate oak (Q. robur) and Sessile oak $(Q$. petrea) in the Bielinek Nature Reserve: comparison of the climatic determinants of tree-ring width. Geochronometria 26:39-40

Chen F, Yuan Y, Wie W, Yu S, Li Y, Zhang R, Zhang T, Shang H (2010) Chronology development and climate response analysis of Schrenk spruce (Picea schrenkiana) tree-ring parameters in the Urumqi River Basin, China. Geochronometria 36:17-22

Cook ER, Holmes R (1999) Users manual for Program ARSTAN. Laboratory of Tree-Ring Research, University of Arizona, Tucson
Cook ER, Kairiukstis LA (eds) (1990) Methods of dendrochronology: applications in the environmental sciences. Springer, Dordrecht / Boston / London

Cook ER, Pederson N (2011) Uncertainty, emergence and statistics in dendrochronology. In: Hughes MK, Swetnam TW, Diaz HF (eds) Dendroclimatology. Progress and prospects. Developments in paleoenvironmental research, Volume 11. Springer, Dordrecht / Heidelberg / London / New York, pp 77-112

Cook ER, Krusic PJ, Jones PD (2003) Dendroclimatic signals in long tree-ring chronologies from the Himalayas of Nepal. Int $\mathrm{J}$ Climatol 23:707-773

Cook ER, Woodhouse CA, Eakin CM, Meko DM, Stahle DW (2004) Long-term aridity changes in the western United States. Science 306:1015-1018

Crawford CJ (2012) Do high-elevation Northern Red Oak tree-rings share a common climate-driven growth signal. Arct Antarct Alp Res 44(1):26-35

Douglas AE (1914) A method of estimating rainfall by the growth of trees. Carnegie Institute of Washington Publication 192: 101-121

Eddy JA (1976) Maunder minimum. Science 192:1189-1202

Ermich K (1959) Badania nad sezonowym przebiegiem przyrostu grubości pnia u Pinus sylvestris L. i Quercus robur L. Acta Soc Bot Pol 28:15-63

Esper J, Shiyatov SG, Mazepa VS, Wilson RJS, Graybill DA, Funkhouser G (2003) Temperature-sensitive Tien Shan tree-ring chronologies show multi-centennial growth trends. Clim Dynam 8:699-706

Esper J, Frank DC, Wilson RJS, Briffa KR (2005) Effect of scaling and regression on reconstructed temperature amplitude for the past millennium. Geophys Res Lett 32:L07711. doi:10.1029/ 2004GL021236

Esper J, Frank DC, Büntgen U, Verstege A, Luterbacher J, Xoplaki E (2007) Long-term drought severity variations in Morocco. Geophys Res Lett 34:L17702. doi:10.1029/2007GL030844

Feliksik E, Wilczyński S (1998) Wpływ warunków termicznych i pluwialnych na przyrost drewna modrzewi (Larix decidua Mill.). Sylwan 3:85-90

Feliksik E, Wilczyński S (2009) The effect of climate on tree-ring chronologies of native and nonnative tree species growing under homogenous site conditions. Geochronometria 33:49-57

Fritts HC (1976) Tree rings and climate. Academic Press, London

Fritts HC, Vaganov EA, Sviderskaya IV, Shashkin AV (1991) Climatic variation and tree-ring structure in conifers: empirical and mechanistic models of tree-ring width, number of cells, cell size, cellwall thickness and wood density. Clim Res 1:97-116

Garciá-Suárez AM, Butler CJ, Baillie MGL (2009) Climate signal in tree-ring chronologies in a temperate climate: a multi-species approach. Dendrochronologia 27(3):183-198

Gea-Izquierdo GG, Cherubini P, Canellas I (2011) Tree-rings reflect the impact of climate change on Quercus ilex L., along a temperature gradient in Spain over the last 100 years. Forest Ecol Manag 262:1807-1816

Gou X, Peng J, Chen F, Yang M, Levia DF, Li J (2008) A dendrochronological analysis of maximum summer half-year temperature variations over the past 700 years on the northeastern Tibetan Plateau. Theor Appl Climatol 93:195-206

Grissino-Mayer HD (2001) Evaluating crossdating accuracy: a manual and tutorial for the computer program COFECHA. Tree-Ring Res 57:205-221

Guiot J, Wu H, Garreta V, Hatté C, Magny M (2009) A few prospective ideas on climate reconstruction: from a statistical single proxy approach towards a multi-proxy and dynamical approach. Clim Past 5:571-583

Helama S, Makarenko NG, Karimova LM, Kruglun OA, Timonen M, Holopainen J, Merilainen J, Eronen M (2009) Dendroclimatic transfer functions revisited: little Ice Age and medieval warm 
period summer temperatures reconstructed using artificial neural networks and linear algorithms. Ann Geophys 27:1097-1111

Hughes MK, Swetnam TW, Diaz HF (2011) Dendroclimatology. Progress and prospects. Developments in paleoenvironmental research, vol 11. Springer Verlag, Heidelberg

Inglot $S$ (1968) Z badań nad wpływem posuchy na rolnictwo na Dolnym Śląsku. Zbiór prac pod kierunkiem B. Świętochowskiego. Z badań nad wpływem posuchy na rolnictwo na Dolnym Ślasku. Prace WTN seria B nr 139, Wrocław

IPCC (2001) Climate Change 2001. The scientific basis. Contribution of the Working Group I to the Third Assessment Report of the Intergovernmental Panel on Climate Change. Cambridge University Press, Cambridge

Jacoby G, D'Arrigo R (1989) Reconstructed Northern Hemisphere annual temperature since 1671 based on high latitude tree-ring data from North America. Clim Chang 14:39-59

Janczak J (1985) Człowiek i przyroda. Przegląd zmian w środowisku geograficznym Śląska w ostatnim tysiącleciu. Dolnośląskie Towarzystwo Społeczno-Kulturalne, Wrocław

Jones PD, Lister DH, Osborn TJ, Harpham C, Salmon M, Morice CP (2012) Hemispheric and large-scale land surface air temperature variations: an extensive revision and an update to 2010. J Geophys Res (in press)

Koprowski M, Przybylak R, Zielski A, Pośpieszyńska A (2012) Tree rings of Scots pine (Pinus sylvestris L.) as a source of information about past climate in northern Poland. Int J Biometeorol 56:1-10

Krapiec M, Szychowska-Krapiec E, Walanus A (2009) Rekonstrukcja termiki okresu zimowego w NE Polsce na podstawie sekwencji przyrostów rocznych sosny zwyczajnej z lat 1582-2004 AD. Prace Komisji Paleogeografii Czwartorzędu PAU, Tom VII: 73-82

Kusza G, Strzyszcz Z (2005) Rezerwaty leśne Opolszczyzny — stan i technogenne zagrożenia. Prace i Studia IPIŚ PAN, Zabrze

Lara A, Aravena JC, Wolodarsky-Franke A, Villalba R, Luckman B, Wilson R (2001) Dendroclimatology of high-elevation Nothofagus pumilio forests in the central Andes of Chile. Can J Forest Res 31:925-936

Li Z, Ming S, Liu Y, Zhang Y, Zhang QB, Ma K (2011) Summer temperature variations from 1710-2005 A.D. as inferred from the tree-ring data of Baimang Snow Mountain, Northwestern Yunnan Province, China. Climate Res 47:207-218. doi:10.3354/cr0101

Michalak S (1971) Rezerwaty przyrody na Opolszczyźnie. Wojewódzki Ośrodek Informacji Turystycznej, Opole

Muter E (2012) Zmienność warunków pogodowych w latach wskaźnikowych u sosny zwyczajnej (Pinus silwestris L.) i dębu szypułkowego (Quercus robur L.) w Puszczy Niepołomickiej. Studia i Materiały CEPL 30: 37-46

Namaczyńska S (1937) Kronika klęsk elementarnych w Polsce i w krajach sąsiednich w latach 1648-1696, Zjawiska meteorologiczne i pomory, Lwów

Niedźwiedź T (2004) Rekonstrukcja warunków termicznych lata w Tatrach od 1550 roku. In: Kotarba A. (ed) Rola Małej Epoki Lodowej w przekształcaniu środowiska przyrodniczego Tatr. Prace Geograficzne 197: 57-88

Niedźwiedź T (2010) Summer temperatures in the Tatra Mountains during the Maunder Minimum (1645-1715), Chapter 19. In: Przybylak R., Majorowicz J., Brázdil R., Kejna M. (eds) The Polish climate in the European context: an historical overview. Springer, Berlin / Heidelberg / New York, pp 397-406

Norman T (1999) Szkody w lasach państwowych Regionalnej Lasów Państwowych w Katowicach wywołane imisjami przemysłowymi, działalnością górniczą oraz rozwojem infrastruktury region. Problemy ekologii 5:169-176

Nowak M (2005) Lasy i gospodarka leśna. In: Drobek W, Heffner K (eds) Ochrona środowiska w województwie opolskim w latach 1993-2003. Instytut Śląski w Opolu, Opole
Nyrek A (1975) Gospodarka leśna na Górnym Śląsku od XVII do połowy XIX wieku. Prace Wrocławskiego Towarzystwa Naukowego, Seria A. 168, Wrocław

Popa I, Cheval S (2007) Early winter temperature reconstruction of Sinaia area (Romania) derived from tree-rings of silver fir (Abies alba Mill.). Rom J Met 9(1-2):47-54

Przybylak R (2012) Changes in Poland's climate over the last millennium. Czasop Geogr 82(1-2):23-48

Przybylak R, Majorowicz J, Brázdil R, Kejna M (2010) The Polish climate in the European context: an historical overview. Springer, Berlin

Rinn F (2010) TSAP - reference manual. Frank Rinn, Heidelberg

Rojecki A (1965) Wyjątki ze źródeł historycznych o nadzwyczajnych zjawiskach hydrologiczno-meteorologicznych na ziemiach polskich od X do XVI. Warszawa

Rolland C, Desplanque C, Michalet R, Schweingruber FH (2000) Extreme tree rings in spruce (Picea abies) (L.) Karst.) and fir (Abies alba Mill.) stands in relation to climate, site, and space in the Southern French and Italian Alps. Arct Antarct Alp Res 32:113

Schulman E (1956) Dendroclimatic changes in semiarid America. University of Arizona Press, Tucson

Speer JH (2010) Fundamentals of tree-ring research. University of Arizona Press, Tucson

Stanisz A (2007) Przystępny kurs statystyki z zastosowaniem Statistica PL na przykładach $z$ medycyny. Modele liniowe i nieliniowe. StatSoft Polska

Stockton CW, Meko DM (1975) A long-term history of drought occurrence in western United States as inferred from tree rings. Weatherwise 28 (6):245-2449

Stokes MA, Smiley TL (1996) An introduction to tree-ring dating. University of Arizona Press, Tucson

Szychowska-Krapiec E (2010) Long term chronologies of pine (Pinus sylvestris L.) and fir (Abies alba Mill.) from the Małopolska region and their paleoclimatic interpretation, Folia Quatern 79, Kraków

Tardif JC, Conciatori F (2006) A comparison of ring-width and event year chronologies derived from white oak (Quercus alba) and northern red oak (Quercus rubra), southwestern Quebec, Canada. Dendrochronologia 23:133-138

Trepińska J (ed) (1997) Wahania klimatu w Krakowie (1792-1995). Wielowiekowe zmiany klimatu na podstawie krakowskiej serii meteorologicznej (1792-1995) ze szczególnym uwzględnieniem schyłku glacjału. IGUJ, Kraków

Trindade M, Bell T, Laroque CP, Jacobs JD, Hermanutx L (2011) Dendroclimatic response of a coastal alpine treeline ecotone: a multispecies perspective from Labrador. Can J For Res 41:469 478

Vaganov EA, Naurazhaev MM, Schweingruber FH, Briffa KR, Moell M (1996) An 840-year tree-ring width chronology for Taimir as an indicator of summer temperature changes. Dendrochronologia 14:193-205

von Storch H, Zorita E, Gonzalez-Rouco F (2009) Assessment of three temperature reconstruction methods in the virtual reality of a climate simulation. Int J Earth Sci (Geol Rundsch) 98:6782

Wagner S, Zorita E (2005) The influence of volcanic, solar and $\mathrm{CO}_{2}$ forcing on the temperatures in the Dalton Minimum (1790-1830): a model study. Clim Dynam 25:205-218

Wazny T, Eckstein D (1991) The dendrochronological signal of oak (Quercus spp.) in Poland. Dendrochronologia 9:35-49

Wettstein J, Littell JS, Wallace JM, Gedalof Z (2011) Coherent Region-, Species-, and Frequency-Dependent Local Climate Signals in Northern Hemisphere Tree-Ring Widths. J Climate 24, doi: 10.1175/2011JCLI3822.1 
Wilczyński S (1999) Dendroklimatologia sosny zwyczajnej (Pinus sylvestris L.) z wybranych stanowisk w Polsce. Praca doktorska. AR Kraków

Wilson RJS, Luckman BH (2002) Tree-ring reconstruction of maximum and minimum temperatures and the diurnal temperature range in British Columbia, Canada. Dendrochronologia 20:257-268

Yadav RR, Park WK, Bhattacharyya A (1997) Dendroclimatic reconstruction of April-May temperature fluctuations in the Western Himalaya of India since A.D. 1698. Quaternary Res 48:187-191
Zhu HF, Fang XQ, Shao XM, Yin ZY (2009) Tree ring-based February-April temperature reconstruction for Changbai Mountain in Northeast China and its implication for East Asian winter monsoon. Clim Past 5:661-666

Zielski A (1997) Uwarunkowania środowiskowe przyrostów radialnych sosny zwyczajnej (Pinus sylvestris L.) w Polsce Północnej na podstawie wielowiekowej chronologii. Wydawnictwo UMK, Toruń 